JKT, 2018;9(1):7-13. Pengaruh Terapi Do’a terhadap Kadar Limfosit Pasien AIDS di Wahyuni Aziza

\title{
PENGARUH TERAPI DO'A TERHADAP KADAR LIMFOSIT PASIEN AIDS DI RUMAH SAKIT UMUM DAERAH DR. M. HAULUSSY AMBON
}

Effect of Pray Therapy to Limfocyt Level of AIDS in Haulussy Hospital Ambon

\author{
Wahyuni Aziza ${ }^{1}$ \\ ${ }^{1}$ Jurusan Analis Kesehatan Poltekkes Kemenkes Maluku, Jalan Laksdya Leo Wattimena, Waiheru, \\ Ambon \\ E-mail: junhar_08@yahoo.com
}

\begin{abstract}
National prevalence of AIDS in Inonesia at 2011 were 10,62/100.000 peoples, in Maluku until June 2012 there was 782 HIV and 245 AIDS with 108 peoples mortality rate. Since 2012 has been developed Comprehensive Continues Services in the public health services level. The services started from preventif, early HIV's test until treatment activities from various field including complementary medicine thus increasing the quality of life of patients AIDS. The complementary therapy has been developed including spiritual therapy. Pray therapy is one of complementary therapy which can increase level of lymphocite. The aims of This research to determine effect of pray therapy to lymphocyte level. Methode of this study used quacy experiment with non randomized control group design with pre test and post test. Samples in the study were 20 peoples. Data were analyzed by using independent T-Test with result showed pray therapy for 30 minutes twice day has a significant effect of lymphocyte level (CD4). This result an be used as a nursing therapy to give spirituality of patient. Nursing maneger can formulate a policy to provide nursing care holistically, provide a format for spiritual assessment and create programs to conduct spiritual nursing to clients.
\end{abstract}

\section{Keywords: HIV/AIDS, pray therapy, lymphocyte level (CD4)}

\begin{abstract}
ABSTRAK
Prevalensi secara nasional kasus AIDS di Indonesia pada tahun 2011 sebesar 10,62 per 100.000 penduduk, di Maluku sampai Juni 2012 terdapat 782 HIV dan 245 AIDS dengan jumlah kematian 108 orang. Sejak tahun 2012 dikembangkan Layanan Komprehensif Berkesinambungan (LKB) ditingkat Puskesmas. Pelayanan dimulai dari upaya pencegahan, tes HIV sedini mungkin sampai pengobatan dari berbagai bidang termasuk komplementer sehingga kualitas hidup pasien AIDS menjadi lebih baik. Terapi komplementer yang dikembangkan diantaranya terapi spiritual, salah satunya adalah terapi do'a yang dapat meningkatkan kadar limfosit (CD4) pasien HIV/AIDS. Penelitian ini bertujuan untuk mengetahui pengaruh terapi do'a terhadap kadar limfosit (CD4) pasien HIV/AIDS, menggunakan desain Kuasi Eksperimen dengan rancangan non randomized control group design with pre test and post test dengan sampel berjumlah 10 orang. Data dianalisis menggunakan independent T-Test dengan hasil menunjukkan bahwa terapi do'a selama 30 menit dua kali sehari berengaruh secara signifikan kadar CD4 pasien HIV/AIDS di RSUD dr. M. Haulussy Ambon. Hasil ini dapat dijadikan salah satu terapi keperawatan untuk memnuhi kebutuhan spiritual pasien. Manajer keperawatan dapat menyusun kebijakan yang mengatur bahwa perawat dalam memberikan asuhan keperawatan bersifat holistik meliputi aspek spiritual, membuat program agar perawat dapat melakukan asuhan keperawatan spiritual kepada klien.
\end{abstract}

Kata Kunci: HIV/AIDS, terapi do'a, kadar limfosit (CD4) 
JKT, 2018;9(1):7-13. Pengaruh Terapi Do'a terhadap Kadar Limfosit Pasien AIDS di Wahyuni Aziza

\section{PENDAHULUAN}

Jumlah total klien HIV/AIDS di dunia pada tahun 2009 cenderung mengalami peningkatan dari tahun ke tahun, meningkat sebesar 20\% dari tahun 2008 dan mengalami peningkatan tiga kali lebih besar dibanding tahun 1990. Jumlah terbanyak terdapat di Negara Sub Sahara-Afrika yaitu 22.4 juta orang. Data bulan November sampai dengan bulan Desember tahun 2009 tercatat klien dengan HIV/AIDS sebanyak 33.4 juta, orang dewasa yaitu 31.3 juta, wanita 15.7 juta, anak-anak dibawah usia 15 tahun 15.7 juta. Klien baru yang terinfeksi HIV/AIDS rata-rata 2.7 juta, kematian akibat AIDS totalnya 2 juta $^{1}$

Di Indonesia hingga Maret 2011 terdapat 24482 kasus AIDS dan 4603 kasus di antaranya telah meninggal dunia. Jumlah tersebut terdiri dari 17840 laki-laki dan 6553 perempuan ${ }^{2}$. Jumlah perempuan yang menderita HIV/AIDS lebih sedikit dibanding laki-laki, meskipun demikian hal ini dapat berdampak bagi perempuan dan remaja putri terutama yang akan menikah dan produktif karena ini akan berpengaruh juga kepada janin yang dikandungnya.

Berdasarkan data dari Dinas Kesehatan Provinsi Maluku angka kejadian HIV/AIDS sebanyak 2179 sampai dengan bulan Desember 2012. Jumlah terbesar terdapat di wilayah Kota Ambon sebanyak 800 kasus, menyusul Kabupaten Maluku Tenggara 200 kasus, Kepulauan Aru 122 kasus dan sisanya tersebar di bebera Kabupaten lain termasuk Kabupaten Maluku Barat Daya dan Buru Selatan. Kasus tertinggi ditemukan pada usia produktif, 15-39 tahun yang sering menggunakan narkoba jenis jarum suntik dan mereka yang berperilaku seks bebas sedangkan di RSUD dr. M. Haulussy Ambon sampai tanggal 25 September 2013 ditemukan 180 kasus dengan jumlah kematian sebanyak 49 orang $^{3}$. RSUD dr. M. Haulussy merupakan rumah sakit rujukan tertinggi di Provinsi Maluku yang memberikan pelayanan kesehatan kepada seluruh masyarakat dengan berbagai kasus termasuk HIV/AIDS.

Kasus HIV/AIDS cenderung meningkat dari waktu kewaktu dan hal ini harus segera ditanggulangi. Penanggulangan HIV/AIDS di Indonesia telah dilakukan sejak tahun 1985 dengan pembentukan kelompok kerja penanggulangan AIDS di Departemen kesehatan, penetapan wajib lapor kasus AIDS, penetapan laboratorium untuk pemeriksaan HIV, penyiapan dan penyebaran bahan komunikasi, informasi dan edukasi (KIE). Puncaknya adalah pada tahun 1994 pemerintah membentuk Komisi Penanggulangan AIDS (KPA) di tingkat Nasional dan disusul oleh terbentuknya KPA di beberapa Propinsi. KPA mulai mengkoordinasikan upaya penanggulangan yang dilaksanakan oleh Pemerintah dan LSM. Strategi penanggulangan HIV/AIDS di Indonesia terus ditingkatkan mengikuti perubahan, tantangan dan masalah HIV/AIDS yang semakin besar dan rumit. Tujuan utamanya yaitu mencegah dan mengurangi penularan HIV, meningkatkan kualitas hidup klien dengan HIV/AIDS serta mengurangi dampak sosial dan ekonomi pada individu, keluarga dan masyarakat yang disebabkan oleh stigma yang melekat pada klien HIV/AIDS ${ }^{1}$. Program pemberantasan penyakit menular termasuk HIV/AIDS dihadapkan pada banyak hambatan termasuk biaya ${ }^{4}$.

Perjalanan dari masuknya virus HIV sampai awal terjadinya gejala AIDS adalah sebagai berikut: Virus HIV tipe 1 dan tipe 2 dikode oleh dua molekul RNA (ssRNA) yang hampir sama. Pada selubung virion terbentuk protein gp120, yang sekaligus melekat pada CD4 dan kemoreseptor kemokin (=CCR5 pada awal infeksi; =CXCR4 pada tahap akhir) di membrane sel penjamu sehingga menyebabkan penyatuan membran dan endositosis virion. Seseorang dengan defek CCR5 akan terlindung dari infeksi HIV. Selain sel CD8, sel CD4-TH terutam ikut terkena. Pada sel CD4-TH, RNA melalui endogen reverse transcriptase virion ditranskripsi menjadi DNA, yang kemudian bergabung menjadi untaian ganda dsDNA (provirus) ke dalam genom sel penjamu (stadium laten) ${ }^{5}$.

Aktivasi sel CD4 memicu ekspresi virus. Protein yang terbentuk, yaitu tat dan rev, juga NFkb dari sel penjamu berperan dalam pembentukan virion baru yang kemudian mengalami eksositosis. Pada stadium ini sel CD4 dapat dihancurkan terutama diserang oleh pertahanan imunnya sendiri (IgG anti gp120 + komplemen; pengenalan peptide virus oleh sel 
$\mathrm{T}$ sitotoksik). Pengobatan yang diberikan pada pasien HIV/AIDS saat ini adalah Antiretroviral (ARV), namun banyak hal yang mempengaruhi keberhasilan pengobatan diantaranya pengetahuan dan dukungan keluarga sesuai dengan hasil penelitian Latif ${ }^{6}$ bahwa ada hubungan antara pengetahuan, persepsi, riwayat efek samping obat, dukungan keluarga dan teman serta interaksi antara pasien dengan petugas layangan Antiretroviral terhadap kepatuhan pengobatan ARV ODHA.

Sejak tahun 2012 ditegaskan agar penanggulangan HIV/AIDS tidak boleh dipisahkan dari prioritas pencapaian Millenium Developmnet Goals ke 6 (MDGs-6). Sejak itulah dikembangkan Layanan Komprehensif Berkesinambungan (LKB) ditingkat Puskesmas. Pelayanan dimulai dari upaya pencegahan, tes HIV sedini mungkin sampai pengobatan dari berbagai bidang termasuk komplementer sehingga kualitas hidup pasien AIDS menjadi lebih baik $^{7}$. Terapi komplementer, diantaranya terapi spiritual namun belum ada penelitain tentang pengaruh terpi do'a pada kadar limfosit pasien HIV/AIDS. Penelitian tentang pentingnya spiritualitas pada penyakit kronis termasuk HIV/AIDS telah banyak dilakukan. Nokes et al ${ }^{8}$ mengatakan bahwa $100 \%$ dari sampel sebanyak 145 orang dengan penyakit HIV menyatakan nyaman dengan terapi komplementer yang dilakukan yang didalamnya terdapat komponen rohani. Klien melaporkan bahwa praktek-praktek spiritual membantu meringankan gejala dan dalam beberapa kasus dapat mengubah prognosis penyakit.

Selain terapi medis ${ }^{9}$ sholat, berdo'a dan berzikir dapat meningkatkan kekebalan tubuh terhadap virus HIV/AIDS, menurutnya orang yang tinggi spritualnya tinggi pula gelombang Alfa di otaknya, ini membuat hidupnya lebih tenang. Pada kondisi demikian tubuh akan mengeluarkan kortisol, epineprine dan norepineprin yaitu hormon-hormon yang mengalir keluar dari kelenjar adrenal untuk menangkal stres.

Saat berdo'a seseorang menjadi tenang dan meningkat rasa percaya diri. Hal tersebut sejalan dengan hasil penelitan Ironson ${ }^{10}$ yang melakukan penelitian pada penderita HIV/AIDS untuk mengetahui pengaruh terapi agama (terapi psikoreligius) terhadap kekebalan tubuh penderita. Kelompok penderita dibagi dua yaitu: kelompok pertama terdiri dari 71 orang dan kelompok kedua terdiri dari 121 orang. Kelompok pertama dalam riwayat kehidupannya banyak menjalankan kegiatan keagamaan, sementara kelompok kedua tidak. Hasil penelitian tersebut menunjukkan bahwa, usia kelompok pertama lebih panjang dari kelompok kedua, sehingga kesimpulan yang diambil adalah bahwa agama mempunyai peran yang penting dalam memperpanjang usia seseorang yang menderita HIV. Penelitian ini bertujuan untuk mengetahui pengaruh terapi do'a terhadap kadar CD4 pasien HIV/AIDS.

\section{METODE PENELITIAN}

Penelitian ini menggunakan desain Quasi Eksperimen dengan rancangan non randomized control group design with pre test and post test. Subjek penelitian terdiri dari 20 orang pasien dengan AIDS dibagi dalam dua kelompok yaitu kelompok perlakukan dan kelompok kontrol. Kelompok perlakukan diberikan terapi ARV dan terapi do'a. Pertama peneliti mengukur kadar limfosit (CD4) kemudian diberikan terapi do'a sebanyak 3 kali seminggu selama 20-30 menit sambil dilanjutkan pemberian ARV, setelah itu diukur lagi kadar CD4 setelah 1 bulan. Untuk kelompok kedua (kelompok kontrol) dengan pemberian ARV yang dimimum setiap hari tanpa do'a yang terstruktur, peneliti mengukur kadar CD4 setelah 1 bulan.

Variabel independen dalam penelitian ini adalah terapi do'a yang diberikan oleh rohaniawan Islam dan Kristen selama 20-30 menit sebanyak 2-3 kali seminggu. Selama berdo'a yang dipimpin oleh rohaniawan, pasien diminta relaks dan tidak melakukan aktivitas lainnya. Do'a dapat dilakukan pada posisi pasien duduk ataupun berbaring. Variabel dependen adalah kadar limfosit (CD4) yang diukur sebelum intervensi dan setelah 1 bulan untuk kedua kelompok. Doa yang diberikan merupakan implementasi dari asuhan keperawatan dalam memenuhi kebutuhan spiritual pasien AIDS, namun pelaksanaannya berkolaborasi dengan rohaniawan. 
Populasi dalam penelitian ini adalah semua pasien HIV di RSUD dr. M. Haulussy Ambon dan sampel penelitan adalah total sampling sebanyak 20 orang dengan teknik incidental samping dengan batasan waktu selama 1 (satu bulan). Selama waktu penelitian hanya ditemukan 20 orang pasien yang dirawat dengan HIV positif.

Data yang diperoleh, dientri dan diolah secara elektronik dengan menggunakan komputer dan selanjutnya diuji melalui 2 tahap yaitu: Analisa Univariat: untuk melihat distribusi frekuensi hasil pengolahan data disajikan dalam bentuk tabel distribusi, frekuensi, dan narasi. Analisa Bivariat: Paired T-Test untuk menganalisa data perbedaan kadar limfosit (CD4) pada kelompok yang diberikan ARV dengan terapi do'a dan yang tidak diberikan terapi do'a dan uji T tidak berpasangan (independent T-Test) adalah untuk melihat perbedaan kadar limfosit (CD4) pada kelompok intervensi dengan kelompok kontrol setelah intervensi.

\section{HASIL}

Tabel 1. Karakteristik responden pada kelompok perlakukan dan kontrol

\begin{tabular}{lccc}
\multicolumn{1}{c}{ Kelompok } & $\begin{array}{c}\text { Jenis Kelamin } \\
(\mathrm{L} ; \mathrm{P})\end{array}$ & $\begin{array}{c}\text { Agama } \\
(\mathrm{I} ; \mathrm{K})\end{array}$ & Umur \pm SD \\
\hline $\begin{array}{l}\text { Perlakuan } \\
(\mathrm{n}=10)\end{array}$ & $5 ; 5$ & $4 ; 6$ & $44 \pm 8,072$ \\
\hline $\begin{array}{l}\text { Kontrol } \\
(\mathrm{n}=10)\end{array}$ & $5 ; 5$ & $3 ; 7$ & $42 \pm 8,171$ \\
\hline
\end{tabular}

Berdasarkan Tabel 1, ditinjau dari umur pasien terbanyak pada umur 41-50 tahun untuk kedua kelompok dan terendah berada pada umur 51-60 tahun. Berdasarkan jenis kelamin untuk kelompok perlakuan sama banyak antara jenis kelamin laki-laki dan perempuan sedangkan pada kelompok kontrol, jenis kelamin laki-laki lebih banyak yaitu $60 \%$. Berdasarkan agama pada kedua kelompok, agama kristen lebih banyak yaitu $60 \%$ pada kelompok perlakuan dan $70 \%$ pada kelompok kontrol.

Perbedaan kadar limfosit (CD4) pada kelompok perlakuan dan kontrol tertera pada Tabel 2 .

Tabel 2. Analisis perbedaan kadar limfosit pada kelompok perlakuan dan kelompok kontrol

\begin{tabular}{|c|c|c|c|}
\hline Kelompok & Pengukuran & $\frac{\text { Mean } \pm \text { SD }}{\text { Kadar Limfosit }}$ & $p$-value ${ }^{a}$ \\
\hline \multirow{2}{*}{$\begin{array}{l}\text { Perlakuan } \\
(\mathrm{n}=10)\end{array}$} & Pre test & $110.70 \pm 23.814$ & \multirow{2}{*}{$.000^{*}$} \\
\hline & Post test & $195.00 \pm 41.476$ & \\
\hline \multirow{2}{*}{$\begin{array}{l}\text { Kontrol } \\
(\mathrm{n}=10)\end{array}$} & Pre test & $127.90 \pm 37.522$ & \multirow{2}{*}{$.017^{*}$} \\
\hline & Post test & $139.80 \pm 37.413$ & \\
\hline
\end{tabular}

Berdasarkan hasil diatas menggambarkan bahwa sebelum dilakukannya perlakuan (pemberian terapi do'a dan ARV) yang diuji melalui pre test kadar CD4 pasien HIV/AIDS semua nilainya sangat rendah. Setelah dilakukan perlakuan (pemberian terapi do'a) diuji melalui post test, tergambar bahwa ada peningkatan kadar CD4 pasien HIV/AIDS. Peningkatan tersebut terlihat dari kadar CD4 setelah perlakuan meningkat pada 90\% pasien. Namun ada 1 orang (1\%) pasien yang kadar CD4 post test lebih kecil dibanding pre testnya.

Uji Paired Samples Statistic kadar CD4 sebelum dan sesudah perlakuan (pemberian terapi do'a) menunjukkan bahwa sebelum diberikan terapi do'a rata-rata kadar CD4 pasien adalah 127.90, sementara setelah diberikan terapi do'a rata-rata kadar CD4 pasien adalah 139.80. Uji Paired Samples Correlation menunjukkan bahwa korelasi antara dua variabel 
adalah sebesar 0.941 dengan signifikansi sebesar 0.000. Hal ini menunjukkan bahwa korelasi antara dua rata-rata kadar CD4 sebelum dan sesudah pemberian terapi do'a adalah kuat dan signifikan.

Untuk kelompok control (hanya diberikan ARV) kadar CD4 sebelum dan sesudah pemberian terapi ARV menunjukkan bahwa sebelum diberikannya ARV rata-rata kadar CD4 pasien adalah sebanyak 127.90, sementara setelah diberikannya terapi ARV rata-rata kadar CD4 pasien adalah 139.80. Paired Samples Correlation, hasil uji menunjukkan bahwa korelasi antara dua variabel adalah sebesar 0.941 dengan signifikansi sebesar 0.000. Hal ini menunjukkan bahwa korelasi antara dua rata-rata kadar CD4 pasien sebelum dan sesudah diberikan terapi ARV adalah tidak kuat dan tidak signifikan.

\section{BAHASAN}

Berdasarkan hasil diatas menggambarkan bahwa sebelum dilakukannya perlakuan (pemberian terapi do'a) yang diuji melalui pre test kadar CD4 pasien HIV/AIDS semua nilainya sangat rendah. Setelah dilakukan perlakuan (pemberian terapi do'a dan ARV) diuji melalui post test, tergambar bahwa ada peningkatan kadar CD4 pasien HIV/AIDS. Peningkatan tersebut terlihat dari kadar CD4 setelah perlakuan meningkat pada 90\% pasien. Namun ada 1 orang (1\%) pasien yang kadar CD4 post test lebih kecil dibanding pre testnya.

CD4 adalah sebuah marker atau penanda yang berada di permukaan sel-sel darah putih manusia, terutama sel-sel limfosit. CD4 pada orang dengan sistem kekebalan yang menurun menjadi sangat penting, karena berkurangnya nilai CD4 dalam tubuh manusia menunjukkan berkurangnya sel-sel darah putih atau limfosit yang seharusnya berperan dalam memerangi infeksi yang masuk ke tubuh manusia. Dengan demikian peningkatan kadar CD4 menunjukkan peningkatan sistem kekebalan tubuh manusia. Pada pemberian ARV umumnya jumlah CD4 akan mulai naik segera setelah kita mulai ARV. Namun kecepatan sangat beragam, dan kadang pelan.

Pada hasil penelitian ditemukan ada 1 (satu) orang setelah perlakuan yaitu pemberian terapi do'a dan ARV mengalami penurunan kadar CD4, menunjukkan bahwa terjadi pula penurunan daya tahan tubuh. Bila jumlah CD4 menurun, perlu dipikirkan bahwa ARV kemungkinan mengalami kegagalan dan perlu dilanjutkan dengan ARV lini kedua ${ }^{7}$. Setelah pemberian terapi do'a juga dapat meningkatkan kadar CD4. Zuhri dalam bukunya Metode Penyembuhan Sufi mengungkapkan bahwa do'a/zikir 2 kali sehari selama 1 jam akan meningkatkan daya tahan tubuh. Do'a/zikir dilakukan pada jam 11 sampai 12 dan 18 sampai 19 dengan cara berdiam dan berdo'a kepada Tuhan untuk kesembuhan, konsentrasi, pikiran tenang dan jangan mengingat hal-hal duniawi, jangan berbicara dengan orang lain dan lakukan evaluasi setelah 12 hari. Doa dalam suasana pasrah penuh kedamaian akan membuat tubuh seseorang mengeluarkan kortisol, epinephrine dan norepinephrine yaitu hormonhormon yang mengalir keluar dari kelenjar adrenal untuk meredakan stres. Zat kimia dalam tubuh ini akan meningkatkan kekebalan dan menghambat berkembangnya penyakit seperti gangguan jantung, stroke, radang usus dan gangguan perut lainnya.

Pasien yang mengalami penurunan kadar CD4 dimungkinkan karena pada saat penelitian pasien belum menerima keadaannya (fase penolakan) sehingga dalam melaksanakan terapi do'anya tidak dilakukan sesuai dengan teori yang ada (pasien kurang tenang, dan waktu berdo'a kadang-kadang sampai 30 menit). Hal ini sesuai dengan pendapat Carrel Aulia do'a itu sering tidak berhasil, karena kebanyakan yang memanjatkan do'a itu masuk golongan orang-orang yang hanya mementingkan diri sendiri, pembohong, penyombong, bermuka dua, tidak beriman dan mengasihi ${ }^{11}$.

Hasil penelitian menunjukkan nilai t hitung adalah sebesar -7.209 dengan signifikansi 0.000. Karena signifikansi $<0.05$ maka dapat disimpulkan bahwa Ho gagal ditolak. Dengan demikian dapat dinyatakan bahwa terapi do'a mempengaruhi kadar CD4 HIV/AIDS di RSUD dr. M. Haulussy Ambon. Hal ini didukung oleh pendapat yang dikemukakan oleh Murphy ${ }^{12}$ mengungkapkan bahwa do'a akan memberikan rasa tenang pada sesorang sehingga akan 
memicu zat kimia dalam tubuh untuk meningkatkan sistem kekebalan tubuh dan menghambat berkembangnya berbagai penyakit, menurutnya meditasi selama 1 jam minimal 2 kali sehari akan meningkatkan daya tahan tubuh.

Selain itu Hawari mengungkapkan bahwa selain terapi medis, sholat, berdo'a dan berzikir dapat meningkatkan kekebalan tubuh terhadap virus HIV/AIDS, menurutnya orang yang tinggi spritualnya tinggi pula gelombang Alfa di otaknya, ini membuat hidupnya lebih tenang. Saat berdo'a seseorang menjadi tenang dan meningkat rasa percaya dirinya. Dalam kondisi demikian tubuhnya mengeluarkan kortisol, epineprine dan norepineprin yaitu hormon-hormon yang mengalir keluar dari kelenjar adrenal untuk menangkal stres ${ }^{13}$.

Hasil penelitian dengan memberikan hanya ARV tanpa terapi do'a menunjukkan bahwa rata-rata kadar CD4 pasien HIV/AIDS sebelum dan sesudah diberikan terapi ARV adalah sama (tidak berbeda). Dengan demikian dapat dinyatakan bahwa terapi ARV saja tidak mempengaruhi kadar CD4 pasien HIV/AIDS di RSUD dr. M. Haulussy Ambon.

Dalam pedoman nasional tatalaksana klinis Infeksi HIV dan terapi Antiretroviral yang dikeluarkan oleh Dirjen Pengendalian Penyakit dan Penyehatan Lingkungan Kementerian Kesehatan ${ }^{14}$ dinyatakan bahwa pemberian ARV diberikan pada ODHA dengan CD4 $\leq 350 \mathrm{sel} / \mathrm{mm}^{3}$ dimulai dengan terapi lini pertama. Pemberian ARV dianjurkan untuk pemantauan lewat pemeriksaan CD4 untuk memastikan ada tidaknya gagal terapi. Kadar CD4 dipakai sebagai indikator kegagalan imunologis terapi dimana dikatakan gagal jika tidak dapat mempertahankan kadar CD4 yang adekuat.

Beberapa pengalaman pasien dengan HIV/AIDS dikatakan bahwa mereka bisa merasa lebih kuat ketika ada terapi lain yang mereka jalani, seperti yang diungkapkan seorang penderita HIV dengan kadar CD4 nol dia bisa bertahan hidup dibantu dengan minum air yang sudah dibacakan do'a.

\section{SIMPULAN}

Terapi do'a selama 30 menit dua kali sehari berpengaruh secara signifikan terhadap kadar CD4 HIV/AIDS di RSUD dr. M. Haulussy Ambon. Dalam penelitian ini terapi doa mempengaruhi kadar CD4 sebelum dan sesudah perlakuan yang diberikan bersamaan dengan pemberian ARV.

\section{SARAN}

Hasil penelitian ini dapat dijadikan salah satu terapi keperawatan dalam memenuhi kebutuhan spiritual pasien sehinggan disarankan manajer keperawatan: menyusun kebijakan yang mengatur bahwa perawat dalam memberikan asuhan keperawatan bersifat holistik meliputi aspek spiritual, menyediakan format pengkajian spiritual, membuat program agar perawat dapat melakukan asuhan keperawatan spiritual kepada klien yang dirawat serta rohaniawan dapat mengunjungi klien yang dirawat di RS secara kontinu dan terencana. Penelitian lanjutan disarankan untuk memperbanyak sampel penelitian.

\section{UCAPAN TERIMA KASIH}

Ucapan terima kasih kami sampaikan pada semua pihak yang telah berpartisipasi dalam penelitian ini.

\section{RUJUKAN}

1. Organization WH. Interim WHO clinical staging of HVI/AIDS and HIV/AIDS case definitions for surveillance: African Region. Geneva: World Health Organization, 2005.

2. Ditjen P, RI PK. Statistik kasus HIV/AIDS di Indonesia. Di unduh dari http://spiritia or id pada tanggal. 2014;14.

3. HIV/AIDS P. Rekapitulasi Data HIV/AIDS, RSUD dr. M. Haulussy Ambon. 2003. 
JKT, 2018;9(1):7-13. Pengaruh Terapi Do’a terhadap Kadar Limfosit Pasien AIDS di Wahyuni Aziza

4. Utomo B. Tantangan Pencapaian Millenium Development Goals (MDGs) Bidang Kesehatan di Indonesia. Kesmas: National Public Health Journal. 2007;1(5):232-40.

5. Smeltzer S, Bare. B.G., Hinkle, J.L., \& Cheever.K.H. Brunner \&Suddarth:textbook of medicalsurgical nursing. Brunner \&Suddarth:textbook of medical-surgical nursing: Lippincott Willian \&Wilkins; 2008.

6. Latif F, Maria IL, Syafar M. Efek Samping Obat terhadap Kepatuhan Pengobatan Antiretroviral Orang dengan HIV/AIDS. Kesmas: National Public Health Journal. 2014;9(2):101-6.

7. P2PL S. Terobosan Pengendalian HIV/AIDS2015.

8. Tuck I, Alleyne R, Thinganjana W. Spirituality and stress management in healthy adults. Journal of Holistic Nursing. 2006;24(4):245-53.

9. Hawari D, Jabar A. Do'a dan dzikir sebagai pelengkap terapi medis: Dana Bhakti Prima Yasa; 1999.

10. Ironson GH, Hayward Hs. Do positive psychosocial factors predict disease progression in HIV-1? A review of the evidence. Psychosomatic medicine. 2008;70(5):546.

11. Willia Novi Aryani W. Metode Terapi Doa bagi Kesehatan Jiwa (Study Kasus Rumah Sakit Umum Daerah Ujungberung Kota Bandung): UIN Sunan Gunung Djati Bandung; 2012.

12. Murphy J abSS. Terapi Do’a. Jakarta: Gramedia Pustaka Utama; 2012.

13. Kylmä J, Vehviläinen-Julkunen K, Lähdevirta J. Dynamics of hope in HIV/AIDS affected people: an exploration of significant others' experiences. Research and theory for nursing practice. 2003;17(3):191.

14. Black JMH, J.H. Medical surgical nursing: Clinical management for positive outcomes. Philadelpia: J.B Saunders; 2009. 